\title{
Penerapan Sistem Pengedalian Intern atas Persediaan Barang pada PT.Mica Jaya Pratama
}

\author{
Pungky Rahmawanti \\ Universitas Islam Batik Surakarta \\ Pungkyrahmawanti@gmail.com
}

\author{
Endang Masitoh \\ Universitas Islam Batik Surakarta \\ yunmasitoh@yahoo.com
}

\author{
Anita Wijayanti \\ Universitas Islam Batik Surakarta \\ Itax_solo@yahoo.com
}

\begin{abstract}
This study aims to find out how the application of internal control over inventory of goods at PT Mica Jaya Pratama Solo. This research is a qualitative research that is by conducting both structured and unstructured interviews to determine the internal control carried out by the company. In this study the variables are the principles of internal control such as adequate separation of duties (organizational structure), determination of adequate responsibilities (system of authority), design and use of documents and adequate records (healthy practices), physical control of assets and records adequate (healthy practice), independently verify performance (HR). The result of this study is that the inventory control system at PT. Mica Jaya Pratama is in accordance with the SOP, but in an adequate separation of duties there is no division between the purchasing division and the finance division.
\end{abstract}

\section{Keywords: Internal Control Systems and Inventory}

\section{Pendahuluan}

Persaingan di dunia usaha saat ini sangat kompetitif. Hal ini mendorong setiap perusahaan untuk meningkatkan daya saingnya. Upaya yang dapat dilakukan perusahaan adalah dengan mengelola dan meningkatkan seluruh aktivitasnya agar mampu bersaing dalam mempertahankan kelangsungan hidup usaha tersebut, sehingga tujuan perusahaan akan tercapai. Pada dasarnya dalam mengelola aktivitas perusahaan yang sangat perlu diperhatikan adalah aktivitas pengelolaan persediaan barang.

Persediaan adalah bagian utama dalam neraca dan seringkali merupakan perkiraan yang nilainya cukup besar yang melibatkan modal kerja yang besar. Persediaan merupakan barang yang dibeli kemudian disimpan untuk dijual dalam operasi normal perusahaan sehingga mendapat perhatian yang besar oleh perusahaan itu sendiri (Seredei, S; Runtu. T., 2015). Persediaan juga sangat rentan terhadap kerusakan maupun pencurian. Oleh karena itu diperlukan suatu pengendalian intern yang bertujuan untuk melindungi persediaan dan juga agar informasi mengenai persediaan lebih dapat dipercaya mengingat aktiva ini tergolong cukup lancar. Tujuan utama dari pengendalian intern persediaan adalah untuk memastikan bahwa persediaan dalam keadaan aman dan disajikan dalam laporan keuangan dengan benar (Srijantri Seredei, 2015).

PT Mica Jaya Pratama merupakan perusahaan yang bergerak di bidang kosmetik. Persediaan barang yang terdapat pada PT 
Mica Jaya Pratama seperti berbagai macam jenis kosmetik yang membutuhkan perlakuan khusus dalam hal penyimpanan di bagian gudang. Pengendalian intern yang dilakukan pada saat ini berdasarkan kebutuhan barang dan belum memperhatikan biaya penyimpanan, biaya pesanan dan biaya lainnya, sehingga menurut pengamatan awal di lapangan yang dilakukan oleh peneliti, sistem pengendalian yang dilakukan oleh PT. Mica Jaya Pratama belum sepenuhnya efektif dan efisien dalam menunjang produksi yang dilakukan. Pengendalian intern terhadap persediaan, diharapkan dapat memberikan dampak yang positif bagi perusahaan. Karena dengan adanya sistem pengendalian intern atas persediaan tersebut akan dapat menekan terjadinya kesalahan dan penyelewengan dari para karyawan perusahaan. Pengendalian intern akan membuat perusahaan berjalan dengan sistem dan prosedur sesuai dengan yang direncanakan.

Sistem informasi persediaan yang baik tidak saja dapat menentukan sistem penjualan apakah dilakukan dengan FIFO atau LIFO dimana pada masing-masing sistem tersebut memiliki kelemahan dan kelebihan sehingga memerlukan suatu evaluasi untuk menentukan sistem apa yang terbaik untuk digunakan dalam penjualan kosmetik (Badaruddin, 2015).

Penelitian mengenai pengendalian intern telah beberapa kali dilakukan, antara lain oleh Tamodia (2013), Nurmaliza (2010), Hariyanto (2010), Kusuma (2011) dan Runtu dan Seredei (2015). Penelitian yang telah dilakukan pengendalian dilakukan dengan pemasangan CCTV, belum dilakukan, pemisahan fungsifungsi akuntansi, belum adanya jadwal rutin pemeriksaan stock yang dilakukan, sehingga peneliti mencoba untuk melakukan pengendalian intern pada persediaan barang dengan lebih efektif dan efisien, yang diharapkan dapat meningkatkan efisiensi dan efektifitas pengendalian intern yang dilakukan oleh perusahaan. Penelitian mengenai pengendalian intern telah beberapa kali dilakukan, antara lain oleh (Tamodia, 2013), (Nurmailiza, 2010), (Kusuma, 2011) dan (Seredei, S; Runtu. T., 2015). Pada penelitian yang telah dilakukan pengendalian dilakukan dengan pemasangan CCTV, belum dilakukan pemisahan fungsi-fungsi akuntansi, belum adanya jadwal rutin pemeriksaan stock yang dilakukan, sehingga peneliti mencoba untuk melakukan pengendalian intern pada persediaan barang dengan lebih efektif dan efisien, yang diharapkan dapat meningkatkan efisiensi dan efektifitas pengendalian intern yang dilakukan oleh perusahaan. Berdasarkan latar belakang masalah di atas, penulis memandang pentingnya pengendalian intern atas persediaan barang dalam perusahaan.

\section{Kajian Pustaka \\ 2.1 Sistem Pengendalian Intern}

Sistem pengendalian intern meliputi struktur organisasi, metode, ukuran-ukuran yang dikoordinasikan untuk menjaga kekayaan organisasi, mengecek ketelitian dan keandalan data akkljuntansi, mendorong efisiensi dan mendorong dipatuhinya kebijakan manajemen (Widya, 2013). Sistem pengendalian intern merupakan suatu proses yang melibatkan semua unsur sumber daya manusia yang ada di perusahaan, termasuk dewan komisaris, manajemen dan seluruh karyawan. Sistem pengendalian internal juga menggunakan teknologi sistem informasi yang dirancang untuk mencapai tujuan tertentu (Agus Purwaji dkk, 2016:3).

\subsection{Prinsip-prinsip Pengendalian Intern}

Berikut prinsip-prinsip pengendalian intern yang efektif (Agus Purwaji, 2016:6)

1) Pemisahan tugas yang memadai.

Pembagian tugas yang ada dalam suatu struktur organisasi didasarkan pada pemisahan antara operasional dan akuntansi, pemisahan antara penanggungjawab aset dan aset yang bersangkutan, pemisahan antara pemberian kuasa atas transaksi-transaksi dan penanggung jawab aset yang bersangkutan, serta pemisahan tugas/kewajiban dalam fungsi akuntansi.

2) Penetapan tanggung jawab yang memadai.

Manajemen perusahaan harus mampu menetapkan siapa yang harus bertanggung jawab atas pekerjaan tertentu. Setiap transaksi yang dilakukan atas nama perusahaan hanya dapat dilakukan dengan persetujuan dari pihak 
yang berwewenang terhadap transaksi tersebut.

3) Perancangan dan penggunaan dokumen serta catatan yang memadai.

Untuk menciptakan pengendalian yang baik, perusahaan harus merancang berbagai dokumen secara cermat dan digunakan dengan benar. Dalam perancangan dokumen, berikut unsur pengendalian intern yang harus dipertimbangkan yaitu pembuatan nomor urut, pencatatan dilakukan pada saat transaksi terjadi dan dokumen dirancang untuk memenuhi berbagai keperluan dalam satu rangkaian sekaligus.

4) Pengendalian fisik atas aset dan catatan yang memadai.

Cara yang baik untuk melindungi aset dan catatan yakni dengan menyediakan perlindungan secara fisik. Peralatan mekanis dan elektronik dapat digunakan untuk menjamin bahwa informasi akuntansi dicatat secara teliti serta tepat waktu.

5) Verfikasi secara independen atas kinerja.

Untuk memastikan bahawa setiap karyawan melaksanakan prosedur pengendalian yang telah ditetapkan, diperlukan verifikasi secara independen terhadap kinerja karyawan. Adapun langkah-langkah verifikasinya sebagai berikut verfikasi dilakukan secara terus menerus dan tanpa pemberitahuan terlebih dahulu, verifikasi harus dilakukan oleh karyawan yang kedudukannya bebas dari karyawan yang sedang diperiksa. Temuan-temuan yang didapat harus segera dilaporkan kepada manajemen untuk segera diambil tindakan yang sesuai.

\subsection{Persediaan Barang}

Persediaan barang dagang pada akuntansi adalah barang yang tersedia di gudang yang tersedia di jual sekarang atau pun di masa yang akan datang, cara memperoleh persediaan barang dagang ini berbagai macam cara diantaranya mengolah sediri dari bahan baku menjadi barang jadi untuk dijual dan atau memperolehnya dari pembelian barang (Seredei, S; Runtu. T., 2015).
Jenis-jenis persediaan dalam suatu perusahaan menurut fungsinya dapat dibedakan atas:

1) Bath Stock/ Lot Size Inventory adalah persediaan yang diadakan karena kita membeli atau membuat bahan-bahan atau barang-barang dalam jumlah yang lebih besar daripada jumlah yang dibutuhkan pada saat itu. Keuntungannya: potongan harga pada harga pembelian, efisiensi produksi dan penghematan biaya angkutan.

2) Fluctuation Stock adalah persediaan yang diadakan untuk menghadapi fluktuasi permintaan konsumen yang tidak dapat diramalkan.

3) Anticipation Stock adalah persediaan yang diadakan untuk menghadapi fluktuasi permintaan yang dapat diramalkan, berdasarkan pola musiman yang terdapat dalam satu tahun dan untuk menghadapi penggunaan, penjualan, atau permintaan yang meningkat.

\section{Metode Penelitian}

Penelitian ini menggunakan jenis penelitian kualitatif, penelitian tentang riset yang bersifat deskriptif dan cenderung menggunakan analisis. Proses dan makna (perspektif subjek) lebih ditonjolkan dalam penelitian kualitatif dengan melakukan interview baik terstruktur maupun tidak terstruktur untuk mengetahui pengendalian intern yang dilakukan oleh perusahaan (Suharsemi, 2014).

\section{Sumber Data}

Sumber data yang digunakan dalam penelitian ini berupa data primer dan data sekunder, yaitu:

1. Data primer

Merupakan data yang diperoleh langsung dari perusahaan atau data yang terjadi di lapangan yang diperoleh dari teknik wawancara, kemudian akan diolah penulis. Wawancara dilakukan terhadap divisi perusahaan yang berkaitan baik secara langsung maupun tidak langsung dengan pengendalian intern persediaan barang dan prosedur penerimaan barang.

2. Data sekunder

Merupakan data yang diperoleh dari perusahaan dalam bentuk yang sudah 
jadi, seperti data mengenai sejarah singkat perusahaan, struktur organisasi, tentang pembagian tugas, dan data lengkap lainnya yang berhubungan dengan pengendalian intern persediaan perusahaan, pada penjualan barang belum ditemukan pemisahan tugas dengan divisi keuangan, atau dengan kata masih terdapat tumpang tindih tanggungjawab fungsional pada divisi ini.

\section{Teknik Pengumpulan Data}

Teknik pengumpulan data dalam penelitian ini meliputi:

1. Wawancara, yaitu mengajukan pertanyaan kepada pihak-pihak yang ada di perusahaan untuk mendapatkan informasi yang berkaitan dengan: pengendalian intern atas persediaan barang, dalam hal ini adalah karyawan PT. Mica Jaya Pratama Solo.

2. Observasi, yaitu mengadakan pengamatan secara langsung terhadap objek yaitu kosmetik yang akan diteliti untuk mendapatkan data-data yang diperlukan sehubungan dengan kepentingan penelitian. Observasi yang peneliti lakukan dengan melihat proses pencatatan barang keluar dan masuk dari dan menuju gudang dan telah sesuai dengan SPI.

3. Dokumentasi, yaitu informasi yang berasal dari catatan atau dokumen penting yang dimiliki perusahaan. Dokumentasi biasanya bisa berbentuk data, gambar, tulisan atau karya monumental dari sebuah organisasi. Dokumentasi adalah proses yang dilakukan secara sistematis mulai dari pengumpulan hingga pengelolaan data yang menghasilkan kumpulan dokumen, yang berupa PO dan surat jalan.

\section{Hasil dan Pembahasan}

\section{Deskripsi Umum Objek Penelitian}

PT Mica Jaya Pratama adalah sebuah perusahaan yang bergerak di bidang kosmetik yang berdiri pada tahun 2014. Kantor pusat PT Mica Jaya Pratama beralamat di Jalan Marina Indah blok G No. 57 Rukan Eksclusive Bukit Golf Mediterania Jakarta Utara sedangkan kantor cabang Solo beralamat di Jalan Sawo Raya 32 Jajar Laweyan.

Produk-produk yang dihasilkan oleh perusahaan ini beragam macam seperti aneka perawatan kulit, lipstik, bedak, minyak wangi, lotion dan sebagainya.

\section{Struktur Organisasi}

Struktur organisasi merupakan gambaran umum secara sistematis mengenai hubungan dan kerjasama sekelompok orang dalam usaha mencapai tujuan bersama. Struktur organisasi PT Mica Jaya Pratama cabang Solo berbentuk organisasi garis dimana wewenang mengalir dari atas ke bawah, yang setiap bagian mempunyai tanggung jawab masing-masing. Struktur organisasi dan uraian tugas pada PT Mica Jaya Pratama cabang Solo lebih jelasnya dapat dilihat pada gambar berikut :

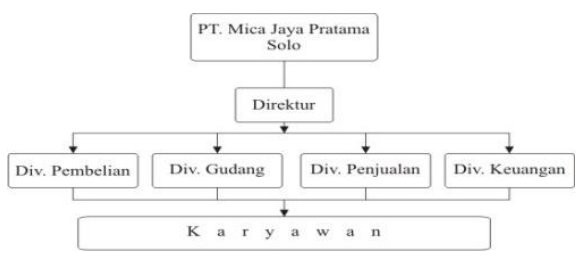

\section{Prosedur Pembelian Barang pada PT.}

Mica Jaya Pratama Solo

Pembelian barang yang dilakukan oleh PT. Mica Jaya Pratama Solo, dilakukan secara berkala sesuai dengan jadwal yang telah disepakati, namun dalam kondisi tertentu pemesanan barang dapat dilakukan sesuai dengan kebutuhan dan permintaan pasar.

Pembelian barang dilakukan sesuai dengan kebutuhan dan tinggi rendahnya penjualan, namun secara periodik tetap dilakukan pembelian untuk menjaga stock persediaan (Wawancara, 30 Juli 2018, dengan Divisi Pembelian).

Pemesanan biasanya dilakukan sebulan dua kali pada tanggal 1 dan 17 setiap bulannya, namun jika terjadi peningkatan penjualan pembelian dapat dilakukan sesuai dengan kebutuhan. (Wawancara, 30 Juli 2018, dengan Divisi Gudang)

Hal ini dilakukan untuk menjaga stok barang agar stabil dan tidak menggangu jalannya penjualan perusahaan. Distributor yang ada, 
disisi lain sering kali tidak memiliki semua barang yang dibutuhkan oleh perusahaan. Antisipasi untuk hal tersebut perusahaan memiliki beberapa distributor yang telah diseleksi menurut kriteria yang dilakukan oleh perusahaan. Adanya klasifikasi distributor selain untuk menjaga ketersediaan barang, juga memberikan keuntungan kepada perusahaan untuk mendapatkan harga yang bersaing.

Tidak, perusahaan memiliki lebih dari satu distributor. Hal ini dilakukan untuk menjaga mutu produk dan tentu saja mendapatkan harga yang bersaing. (Wawancara, 30 Juli 2018, dengan Divisi Keuangan).

Tidak, perusahaan memiliki beberapa supplier, namun supplier tersebut kita beri peringkat berdasarkan beberapa kriteria yang ditetapkan perusahaan, supllier dengan peringkat tertinggi merupakan pilihan utama perusahaan. (Wawancara, 30 Juli 2018, dengan Divisi Pembelian)

Pembelian barang yang dilakukan oleh Divisi Pembelian dilakukan dengan koordinasi divisi lain dan juga dilakukan dengan permintaan tertulis dengan otorisasi dari kepala divisi, hal ini dilakukan sebagai salah satu pengawasan intern yang dilakukan oleh perusahaan.

Pasti mbak, adanya persetujuan dengan divisi pembelian, gudang dan juga divisi keuangan. (Wawancara, 30 Juli 2018, dengan Divisi Pembelian)

Mengenai otorisasi tertulis yang dilakukan, terlihat dari hasil wawancara berikut ini:

Ya pasti, catatan pasti dibutuhkan walaupun saat ini semua sistem pemesanan dapat dilakukan melalui surat elektronik dan stok persediaan juga sudah dapat dilihat melalui aplikasi komputer (Wawancara, 30 Juli 2018, dengan Divisi Pembelian)

Ya betul sekali, selalu diadakan koordinasi antar divisi (Wawancara, 30 Juli 2018, dengan Divisi Gudang)

Ada catatan pembelian, penjualan, bahkan persediaan barang digudang, namun tiap divisi memiliki akses tertentu untuk melihat data base (Wawancara, 30 Juli 2018, dengan Divisi Penjualan)
Prosedur pembelian dan pemesanan barang yang dilakukan oleh perusahaan secara lengkapnya adalah sebagai berikut:

a. Prosedur Pembelian Barang

PT. Mica Jaya Pratama Solo adalah kantor cabang, sehingga tidak ada pembelian yang dilakukan oleh PT. Mica Jaya Pratama Solo. Pengadaaan barang dalam perusahaan melakukan order kepada kantor pusat berdasarkan permintaan dari bagian gudang atau penjualan. Seluruh pembelian barang dilakukan oleh kantor pusat, yang selanjutnya dikirim ke PT. Mica jaya Pratama sebagai cabang.

Proses Permintaan Barang :

a) Divisi pembelian melakukan permintaan barang ke kantor pusat berdasarkan booking dari Div. Penjualan melalui surat, dan atau purchase order.

b) Divisi pembelian melengkapi PO dengan tanggal pengiriman, jumlah barang yang diingkan dan syarat lain yang diperlukan.

c) Divisi pembelian memonitor barang yang dibeli berdasarkan Kartu Stock.

d) Divisi pembelian menerima barang dengan verifikasi surat jalan dengan memberi paraf dan tanggal barang datang untuk diserahkan ke bagian yang membutuhkan, kemudian divisi pembelian menerima Nota Penerimaan dari bagian yang telah menerima barang.

e) Divisi gudang melakukan pemeriksaan terhadap barang yang datang, apabila terdapat ketidaksesuaian akan dikomunikasikan ke divisi pembelian.

b. Sistem dan Prosedur Pembelian Barang

1) Fungsi yang terkait

Sistem pembelian barang pada PT. Mica Jaya Pratama Solo melibatkan beberapa fungsi yaitu fungsi penjualan, fungsi pembelian, fungsi keuangan dan fungsi akuntansi.

2) Dokumen yang digunakan 
Dokumen yang digunakan dalam sistem pembelian barang pada PT. Mica Jaya Pratama Solo ialah purchase order, bon penerimaan/ surat jalan dan nota intern.

3) Catatan akuntansi yang digunakan

Catatan akuntansi yang digunakan dalam sistem pembelian barang pada PT. Mica Jaya Pratama Solo ialah jurnal pembelian dan buku pemantau harian/ kartu stok.

4) Jaringan prosedur yang membentuk sistem

Jaringan prosedur yang membentuk sistem pembelian pada PT. Mica Jaya Pratama Solo adalah prosedur permintaan pembelian, prosedur order barang, prosedur penerimaan barang dan prosedur pembayaran.

\section{Prosedur Penerimaan Barang Gudang} Barang pada PT. Mica Jaya Pratama Solo

Proses pembelian yang dilakukan diikuti dengan proses penerimaan barang yang dilakukan oleh divisi gudang. Sebelum barang dimasukkan kedalam gudang, dilakukan pemeriksaan baik secara kualitas maupun kuantitas dari barang yang diterima pencocokan melalui surat jalan.

Sebelum masuk kedalam gudang dilakukan pemeriksaan terhadap produk yang diterima, baik secara kualitas, maupun jumlahnya, apakah telah sesuai dengan pemesanan yang dilakukan. (Wawancara, 30 Juli 2018, dengan Divisi Pembelian)

Tidak pernah, sebelum masuk gudang barang yang diperiksa selalu dilakukan pemeriksaan baik untuk kualitas ataupun kuantitasnya (Wawancara, 30 Juli 2018, dengan Divisi Penjualan)

a. Prosedur Penerimaan Barang Gudang

1) Divisi gudang menerima barang baik barang berdasarkan purchase order dan surat jalan dari bagian pembelian.

2) Surat jalan ditandatangani terlebih dahulu oleh bagian pembelian sebelum barang diterima oleh divisi gudang.

3) Barang dimintakan validasi oleh divisi gudang terlebih dahulu ke

$$
\text { divisi penjualan dengan }
$$

menggunakan persetujuan barang.

b. Sistem dan Prosedur Penerimaan Barang Gudang

Sistem penerimaan barang gudang pada PT. Mica Jaya Pratama Solo melibatkan beberapa fungsi antara lain:

a) Fungsi Penerimaan

Fungsi ini bertugas menerima barang dan memberikan validasi pada surat jalan yang diterima dari pemasok. Fungsi ini dilaksanakan oleh Divisi pembelian.

b) Fungsi Gudang

Fungsi ini bertugas menerima barang dari bagian pembelian dan kemudian menyimpannya di dalam gudang. Fungsi ini dilaksanakan oleh Divisi gudang

c) Fungsi Pengecekan

Fungsi ini bertugas untuk melakukan pengecekan kualitas barang yang diterima. Fungsi ini dilaksanakan oleh Divisi Gudang

d) Fungsi Penjualan

Fungsi ini bertugas untuk memberikan validasi kepada divisi gudang mengenai barang yang diterima. Fungsi ini dilaksanakan oleh divisi penjualan.

\section{PEMBAHASAN}

Berdasarkan uraian sebelumnya dan penelitian yang telah peneliti lakukan, peneliti akan melakukan evaluasi terhadap sistem pengendalian intern persediaan pada PT. Mica Jaya Pratama Solo. Berikut ini evaluasi sistem pengendalian intern persediaan pada PT. Mica Jaya Pratama Solo:

\section{Pemisahan Tugas yang Memadai (Struktur Organisasi)}

a. Fungsi penjualan

Fungsi penjualan yang dilaksanakan oleh divisi penjualan bertugas melakukan perhitungan kebutuhan barang dalam satu periode pemesanan kemudian melakukan booking kepada divisi pembelian untuk memesan barang yang dipesan tersebut.

b. Fungsi pembelian

Fungsi pembelian yang dilaksanakan oleh divisi penjualan bertugas melakukan pemesanan dan pembelian 
barang yang diperlukan kepada kantor pusat dan menerima barang pada saat barang tersebut telah tiba.

c. Fungsi penyimpanan barang Divisi gudang sebagai fungsi penyimpanan barang bertugas menerima barang dari divisi pembelian dan memeriksa kuantitas barang yang diterima.

d. Fungsi pengecekan barang

Pengecekan kuantitas dan kualitas barang dilaksanakan oleh divisi gudang.

Pelaksanaan pengawasan intern yang dilakukan oleh PT. Mica Jaya Pratama Solo khususnya dalam pemisahan tanggungjawab fungsional belum berjalan dengan baik. Hasil dari temuan dilapangan diketahui bahwa Divisi Pembelian dan Divisi Keuangan masih dilakukan oleh satu orang penanggungjawab. Hal itu tidak sesuai dengan pendapat Widya (2013) yang menyatakan bahwa sistem pengendalian barang yang dilakukan antara lain adanya pemisahan tanggungjawab sesuai dengan struktur organisasi dan adanya pertanggungjawaban antar divisi.

Pertanggungjawaban dua divisi yang ada di PT. Mica jaya Pratama Solo hanya kepada satu orang, juga tidak sesuai dengan prinsip pengendalian yang efektif menurut Purwaji (2016) yang menghendaki adanya pemisahan tugas yang ada dalam struktur ogranisasi sehingga tiap divisi memiliki pertanggungjawaban masing-masing sesuai tugas dan fungsinya. Selain itu, masih menurut Purwaji (2016) pertanggungjawaban yang dilakukan oleh satu orang atas dua divisi juga menyulitkan adanya penilaian atas kinerja yang dilakukan secara independen.

Hasil penelitian ini dimana masih belum terdapat pemisahan sebagaimana yang terlihat pada struktur organisasi memberikan hasil yang berbeda dari penelitian sebelumnya yang dilakukan oleh Tamodia (2013), dan Nurmailiza (2010) dimana pada kedua penelitian tersebut, sudah ada pemisahan antara masing-masing divisi sesuai dengan tanggungjawab pada struktur organisasi perusahaan. Namun hasil penelitian ini sejalan dengan penelitian yang dilakukan oleh Kusuma (2011) dimana pada penelitian tersebut ditemukan belum adanya pemisahan antara divisi gudang dengan bagian lainnya sehingga pengeluaran obat dari gudang kurang mendapat pengawasan dan menyulitkan dalam pengendaliannya.

Transaksi pembelian pada PT. Mica Jaya Pratama Solo belum dijalankan oleh lebih dari satu fungsi. Hal ini akan mempersulit terciptanya internal check, otorisasi dan prosedur pencatatan telah sesuai dengan Standard Operating Procedure. Kondisi yang ada pada PT. Mica Jaya Pratama Solo bertentangan dengan prinsip pengendalian intern yang seharusnya dilakukan dimana pada pengendalian intern tersebut seharusnya meliputi (Purwaji, 2016) : pemisahan tugas yang memadai yaitu pembagian tugas yang ada dalam suatu struktur organisasi didasarkan pada pemisahan antara operasional dan akuntansi, pemisahan antara penanggungjawab aset dan aset yang bersangkutan, pemisahan antara pemberian kuasa atas transaksi-transaksi dan penanggung jawab aset yang bersangkutan. Serta pemisahan tugas/kewajiban dalam fungsi akuntansi.

2. Penetapan Tanggung Jawab yang Memadai (Sistem Wewenang)

Sistem pencatatan dan wewenang yang ada di PT Mica Jaya Pratama Solo telah berjalan hal ini terlihat adanya kelengkapan dokumen dan pencatatan yang dilakukan oleh perusahaan. Pada divisi pembelian terdapat catatan kebutuhan barang yang dinginkan, PO yang digunakan untuk melakukan pemesanan barang terhadap divisi pembelian, sedangkan pada divisi pembelian juga terdapat rekap kebutuhan barang yang diingkan oleh devisi penjualan, tanda bukti penerimaan barang dan surat jalan yang dikirim oleh kantor pusat sebagai bukti.

Selanjutnya pada divisi gudang terdapat pula catatan berkenaan dengan barang yang diterima, kualitas dan jumlah barang dan bukti penerimaan barang, dan pada divisi keuangan terdapat catatan stok barang dan bukti pembayaran ke kantor pusat terhadap barang yang telah dikrimkan.

Unsur pengendalian internal berkenaan sistem wewenang dan pencatatan serta pemisahan masing-masing sudah terlihat dan dilaksanakan oleh PT Mica Jaya Pratama Solo. Sesuai dengan teori (Purwaji, 2016) bahwa manajemen perusahaan harus mampu menetapkan siapa yang harus bertanggung jawab atas pekerjaan tertentu. Setiap transaksi 
yang dilakukan atas nama perusahaan hanya dapat dilakukan dengan persetujuan dari pihak yang berwewenang terhadap transaksi tersebut.

3. Perancangan dan Penggunaan Dokumen serta Pengendalian fisik dan aset (Praktik Sehat)

Perusahaan telah melakukan praktik yang sehat, yaitu:

a. Penggunaan dokumen sudah bernomor urut tercetak.

b. Buku pemantau harian diisi dan dilengkapi oleh bagian pembelian. Pada saat pemesanan berdasarkan purchase order dan saat barang sudah diterima berdasarkan nota intern. memeriksa kuantitas barang yang diterima, apabila terdapat ketidaksesuaian akan dikomunikasikan ke divisi pembelian.

c. Bagian gudang memeriksa kualitas barang yang diterima, apabila terdapat ketidaksesuaian akan dikomunikasikan ke divisi pembelian.

d. Nota penerimaan barang dibuat setelah semua proses pengecekan selesai dilaksanakan.

\section{Verifikasi Atas Kinerja (Sumber Daya} Manusia)

Verifikasi atas kinerja yang antara lain diwujudkan kompetensi karyawan dalam melakukan pekerjaan sesuai dan tugas dan tanggungjawabnya dilakukan melalui seleksi pada saat penerimaan karyawan. Karyawan PT. Mica Jaya Pratama Solo yang berkompeten dipilih dengan menyeleksi calon karyawan berdasarkan persyaratan yang dituntut oleh pekerjaannya. Pelaksanaan pekerjaan berdasarkan uraian jabatan dan tanggung jawab pekerjaan masing-masing.

Selain itu secara internal PT Mica Jaya Pratama melakukan penilian terhadap kinerja karyawan, hal ini dilakukan oleh kantor pusat secara berkala, karyawan/ staf PT. Mica Jaya Pratama yang kinerjanya kurang baik atau tidak sesuai dengan standar perusahaan akan mendapat surat peringatan.

Adanya seleksi dan pengawasan terhadap kinerja yang dilakukan oleh karyawan dan staf mnenunjukkan bahwa verifikasi atas kinerja karyawan/ staf telah dilakukan dengan baik oleh PT. Mica Jaya Pratama.

\section{Kesimpulan, Keterbatasan, dan Saran}

\section{Kesimpulan}

Berdasarkan pembahasan dan evaluasi yang telah dijelaskan pada bab sebelumnya, maka peneliti dapat mengambil kesimpulan bahwa sistem pembelian pada PT. Mica Jaya Pratama Solo sudah sesuai dengan Standard Operating Procedure. Hal ini tercermin dari adanya hal-hal berikut:

1. Belum terdapat pemisahan fungsi yang terpisah antara fungsi penjualan dengan fungsi pembelian dan fungsi keuangan.

2. Telah terlaksananya otorisasi oleh pihak yang berwenang terhadap dokumen yang digunakan dalam setiap transaksi. Pencatatan transaksi ke dalam catatan akuntansi didukung oleh dokumen sumber dan pendukung.

3. Praktik sehat telah dilakukan oleh perusahaan, yang antara lain ditunjukkan dengan adanya penomoran dokumen dan adanya arsip mengenai pembayaran, pembelian dan penjualan yang dimiliki oleh perusahaan.

4. Verifikasi atas kinerja dilakukan dengan seleksi terhadap kualitas SDM terhadap karyawan yang akan bekerja pada perusahaan, serta adanya pengawasan dari kantor pusat terhadap karyawan/ staff PT. Mica Jaya Pratama Cabang Solo.

\section{Keterbatasan}

Penelitian yang dilakukan memiliki keterbatasan dalam memperoleh hasil wawancara yaitu staff divisi-divisi belum kooperatif dalam menjawab pertanyaanpertanyaan dari peneliti. Keterbatasan lainnya yaitu tidak semua dokumen dan laporan diberitahukan kepada peneliti.

Saran

Berdasarkan penelitian dan kesimpulan yang telah peneliti lakukan, beberapa saran yang dapat diberikan adalah:

1. Kepada narasumber diharapkan lebih kooperatif dalam menjawab pertanyaan dari peneliti.

2. Kepada peneliti selanjutnya diharapkan bisa melakukan pendekatan dengan pihak narasumber agar mendapatkan dokumen-dokumen yang lengkap. 


\section{DAFTAR PUSTAKA}

Al Fatta, Hanif. 2016. Analisis dan Perancangan Sistem Informasi: ANDI. Yogyakarta.

Badaruddin, Ahmad. 2015. Sistem Pengendalian Barang. Pustaka Rajawali. Bandung

Baridwan, Zaki. 2014, Intermediate Accounting, Edisi Kedelapan, Yogyakarta; BPFE.

Bodnar, George H.J. dan Hopwood, William S. 2014. Sistem Informasi Akuntansi. Edisi 9: ANDI. Yogyakarta

Bringham, E. F dan Houston, 2016. Dasardasar Manajemen Keuangan. Ed 10. Alih Bahasa Ali Akbar Yulianto: Salemba Empat Jilid 1. Jakarta.

Gitosudarmo, Indriyo, 2012. Manajemen Keuangan. Edisi Keempat: BPFE. Yogyakarta.

Gordon B. Davis, 2013. Kerangka Dasar System Informasi Manajemen Bagian I Pengantar.

Hansen dan Mowen. 2015. Akuntansi Manajerial. Buku 1 Edisi 8: Salemba Empat. Jakarta.

Husein, Muhammad Fakhri dan Amin Wibowo. 2012. Sistem Informasi Manajemen. Yogyakarta : UPP AMP YKPN,

Jogiyanto HM. 2013. Sistem Teknologi Informasi: ANDI. Yogyakarta.

Kusuma, Anindita W. 2011. Analisis Pengendalian Internal Persediaan Obat pada Apotek Kencana Semarang. Skripsi Fakultas Ekonomi dan Bisnis Universitas Dian Nuswantoro, Semarang.
Lexy J. Moloeng. 2015. Metode Penelitian Kualitatif. Bandung: PT. Remaja Rosdakarya

Mulyadi. 2012. Sistem Akuntansi. Edisi 3: Salemba Empat. Jakarta

Mulyadi. 2033. Sistem Akuntansi. Jakarta: Salemba Empat.

Ni Luh Sari Widhiyani. (2007). Desain Sistem Informasi Akuntansi Persediaan Berbasis Komputer pada Perusahaan Konstruksi.Skripsi. Universitas Udayana.

Nuraini, Siti. 2011. Perancangan Sistem Akuntansi Persediaan Barang Dagang Terkomputerisasi pada Beta Jaya Furniture dan Bahan Meubel. Skripsi. UNY

Nurmailiza, Tengku. 2010. Analisis Pengendalian Intern atas Persediaan Barang Dagang pada PT Sabda Cipta Jaya. Skripsi Fakultas Ekonomi Universitas Sumatera Utara, Medan.

Purwaji, A. dan Wibowo. 2016. Pengantar Akuntansi 2. Edisi 2, Salemba Empat. Jakarta Selatan.

Randol J. ELDER. 2011. Audit Dan Jasa Assurance Jilid 2, Jakarta : ERLANGGA

Raymond McLeod, Jr. System Informasi Manajemen, penerjemah: Hendra Teguh SE,AK. editor: Hardi Sukardi MBA,Msc.,SE (MM UI).

Romney, Marshall, B. dan Steinbart. 2003. Accounting Information System. Nineth Edition. Pearson Education, Inc.

Seredei, S. Dan Runtu. T. 2015. Evaluasi Penerapan Pengendalian Intern atas Persediaan Barang Dagangan pada PT Suramando (Distributor Farmasi dan General Supplier) di 
Manado. Jurnal EMBA. Vol.3

No.2 Hal. 385-394.

Tamodia, Wahyu. 2013. Evaluasi Penerapan Sistem Pengendalian Intern untuk Persediaan Barang Dagangan pada PT Laris Manis Utama Cabang Manado. Jurnal EMBA Vol.1 No.3 Juni 2013. Manado: Universitas Sam Ratulangi.

Wilkinson, J. W, dan Cerullo, M.J dan Raval, $\mathrm{V}$, serta Wong-Om-Wing, B. 2012. Accounting Information System: Essential Concept and Aplication, 4th ED. John Wiley and Sonds, Inc. New York.

Winarno, W.W. 2016. Sistem Informasi Akuntansi. Edisi 2: UPP STIM YKPN. Yogyakarta. 